\title{
Fairness og statsborgerskab
}

Kristian Kriegbaum Jensen, postdoc, Institut for Politik og Samfund, Aalborg Universitet \& Lasse Nielsen, lektor, Institut for Kulturvidenskaber, Syddansk Universitet

De danske krav til statsborgerskab begrundes ofte med et ideal om at belønne personlig indsats og individuelt ansvar. Et lignende ideal kendes fra held-egalitarismen, som er blandt de mest udbredte og anerkendte retfcerdighedsteorier indenfor nutidig politisk teori. Denne artikel opstiller et held-egalitaristisk argument for de danske krav for tildeling af statsborgerskab, og undersøger i lyset heraf, hvorvidt kravene i relevant forstand afspejler indsats og ansvar. Artiklen konkluderer afvisende, og foreslår nogle måder hvorpå den danske statsborgerskabspolitik kan gøres mere fair ${ }^{1}$.

\section{Introduktion}

"Vi fører en stram, men fair udlændingepolitik", slog statsminister Mette Frederiksen fast i valgkampen sidste år. Denne og lignende vendinger anvendes jævnligt, når særligt Venstre og Socialdemokratiet præciserer principperne bag deres udlændingepolitik. Når dette princip uddybes i forhold til reglerne omkring statsborgerskab - som kun angår de, som har opholdstilladelse - så handler det om personlig indsats (ofte benævnt "vilje til integration" i debatten). Statsborgerskab er noget man skal gøre sig fortjent til ved at yde en tilstrækkelig indsats; noget "specielt" man skal "række ud efter", som det også ofte formuleres. Man skal tage ansvar for egen integration og gøre sit bedste for at lære sproget, få sig et arbejde og lære landet og kulturen at kende. En tilstrækkelig indsats belønnes med statsborgerskab. Dette afspejler en grundlæggende intuition om fairness - at fordelingen af ressourcer skal afspejle individers indsats - som er bredt delt på tværs af kulturer og aldersgrupper (Hansen 2018, 16-18).

I hvilken grad dette udtrykker et reelt og tungtvejende politisk ønske om fair statsborgerskabskrav - og udlændingepolitik mere generelt - og i hvilken grad, der blot er tale om retorik, skal vi lade stå åbent. Men interessant er det, at sloganet præger den brede midte af dansk politik. Der er selvfølgelig partier, særligt på højrefløjen, som stiller sig kritiske over for ambitionen om åbenhed, alt imens partier på venstrefløjen ønsker en mindre stram politik.

På trods af den brede opslutning bag ideen om en stram og fair politik, er det uklart, om de danske krav til statsborgerskab - som i et europæisk perspektiv er endog

\footnotetext{
${ }^{1}$ Vi er taknemlige for nyttige kommentarer fra Kristina Jessen Hansen, Christian Albrekt Larsen, Andreas Albertsen, Troels Fage Hedegaard og Simon Laumann Jørgensen.
} 
meget stramme (Goodman 2014; Jensen et al. 2019) - i tilstrækkelig grad belønner personlig indsats og ansvar. Dette spørgsmål forfølger artiklen ved at foretage en normativ analyse af de eksisterende statsborgerskabskrav. Analysen baseres på held-egalitarismen, en normativ politisk teori med grundsynspunktet, at en fair fordeling af goder afspejler folks individuelle ansvar og udligner forskelle, som skyldes held og uheld. Som vi skal se, er der ikke nogen nødvendig modsætning imellem et ønske om en stram statsborgerskabspolitik og et hensyn til held-egalitaristisk fairness. Men det kræver afgørende revisioner af de krav, vi i dag stiller til indvandrere uden dansk statsborgerskab.

I det følgende diskuterer vi først, hvorfor statsborgerskab er vigtigt og præsenterer kort de danske krav. Herefter opridses nogle grundideer fra held-egalitarismen, og vi opstiller et argument for statsborgerskabskrav, som det ville se ud baseret på held-egalitaristiske præmisser. Argumentet afslører, at de eksisterende statsborgerskabskrav ikke tilfredsstillende afspejler personlig indsats. Det følger ikke af denne normative analyse, at der nødvendigvis er noget galt med de danske krav, men analysen problematiserer antagelsen om, at de danske krav indeholder en mulighedslighed, som i relevant forstand afspejler et hensyn til fairness. De resterende sektioner diskuterer, hvordan man kan indrette henholdsvis et sprogkrav, et selvforsørgelseskrav og et videnskrav, så de bedre afspejler og måler personlig indsats.

\section{Hvorfor er statsborgerskab vigtigt?}

Hvilke rettigheder opnås med statsborgerskab (eller indfødsret, som er den juridiske term)? Faktisk ikke mange. Særligt er det retten til at stemme og opstille ved nationale valg, sikkerhed fra at blive deporteret (selvom der nu er åbnet op for, at man kan fratage det danske statsborgerskab fra personer med dobbelt statsborgerskab som 'fremmedkrigere' eller særligt hårde kriminelle), ingen begrænsninger i forhold til hvilke erhverv man kan besidde (eksempelvis kræver politiet, at ansatte har statsborgerskab), større bevægelsesfrihed i udlandet (man kan altid vende tilbage til Danmark efter udlandsophold af enhver varighed, og det danske pas giver visumfritagelse i en række lande). At der alligevel ikke er tilknyttet flere rettigheder-eksempelvis sociale rettigheder - til statsborgerskabet, ses af visse forskere som del af en udvikling, hvor internationale konventioner og menneskerettighedsnormer begrænser mulighederne for at differentiere rettigheder på baggrund af nationalitet, og som en nærmest nødvendig konsekvens af det liberale demokratis ligheds- og frihedsforpligtelser på tværs af etniske og kulturelle skel (Joppke 2010; Soysal 1994).

Ud over disse rettigheder kan statsborgerskab have en positiv betydning for indvandreres livskvalitet og muligheder. En række sociologiske og økonomiske studier, hvoraf flere anvender eksperimentelle metoder, viser, at statsborgerskab har en positiv effekt på politisk integration (Bevelander 2015; Hainmueller et al. 2015; Street 2017), social integration (Hainmueller et al. 2017) samt arbejdsmarkedsintegration (Bevelander og Pendakur 2012; Corluy et al. 2011; Gathmann og Keller 2018; Peters et al. 2018). Det 
tyder således på, at statsborgerskabet er forbundet med en form for anerkendelse fra det omkringliggende samfund samt en følelse af større samhørighed fra indvandrernes side.

Hvilke krav skal indvandrere så leve op til for at få dansk statsborgerskab? For det første, skal man bestå en danskprøve på B2 niveau (såkaldt Dansk 3 eksamen), man må ikke have modtaget hjælp efter lov om aktiv socialpolitik eller integrationsloven ${ }^{2}$ indenfor de sidste to år samt ikke mere end højst 4 måneder indenfor de sidste fem år, og man skal bestå en indfødsretsprøve, hvor man på 45 minutter skal svare korrekt på mindst 32 af 40 'multiple choice'-spørgsmål (hvoraf fem spørgsmål ikke kan læres via pensum). Herudover er der karensperioder for kriminalitet (ved særligt hårde domme afskrives ens mulighed for statsborgerskab fuldstændigt), krav om ingen offentlig gæld, og at man skal afgive en loyalitetserklæring og deltage i en kommunal grundlovsceremoni. Særligt for det danske system er, at tildelingen af statsborgerskab ikke er en ren forvaltningsafgørelse, men afgøres halvårligt af Folketinget gennem lovforslag om indfødsretsmeddelelse. Skønt det yderst sjældent forekommer, så kan indfødsretsudvalget vælge at tage personer af lovforslaget selvom, de opfylder alle krav.

Der er næppe tvivl om, at sprogkravet og selvforsørgelseskravet udgør de største barrierer for adgangen til statsborgerskab (Jensen et al. 2019), samt at ikke-vestlige flygtninge og indvandrere, for hvem statsborgerskabet givetvis har større værdi, da deres hjemlande i højere grad er præget af usikkerhed og ustabilitet (Peters, Vink og Schmeets 2016), har sværere ved at efterleve kravene, fordi de generelt har lavere uddannelse.

De danske statsborgerskabskrav er blandt de mest krævende i Europa, og det kan diskuteres, om de ikke endda er de mest restriktive overhovedet (se Goodman 2014 og Jensen et al. 2019). Kravene gælder endda også for personer født i Danmark, hvis forældre ikke har dansk statsborgerskab eller ikke får det i løbet af pågældendes barndom. De fleste held-egalitarister vil stille sig kritiske overfor en praksis, hvor kun nogle af de, som (tilfældigt) fødes i et givent land, opnår statsborgerskab automatisk (eller ved erklæring). Det er dog en separat diskussion (men se Brezger og Cassee 2016; Ferracioli 2017). Denne artikel fokuserer på de krav, der stilles til førstegenerationsindvandrere.

Før vi kommer til diskussionen af, hvorvidt de danske krav til sprog, selvforsørgelse og viden er følsomme over for forskelle i indvandreres personlige integrationsindsats, præsenteres først nogle grundlæggende held-egalitaristiske tanker om forholdet mellem personligt ansvar og fordelingsretfærdighed samt et overordnet held-egalitaristisk argument for at have statsborgerskabskrav.

\footnotetext{
${ }^{2}$ Dette dækker blandt andet over følgende ydelser: kontanthjælp, uddannelseshjælp, revalideringsydelse, ressourceforløbsydelse, ledighedsydelse og integrationsydelse.
} 


\section{Fairness og statsborgerskabskrav}

Spørgsmål om, hvilken betydning individers egne frie valg og indsats bør spille for fordelingen af vigtige goder, undersøges ofte i held-egalitaristiske diskussioner. Den grundlæggende tanke i held-egalitarismen er, at det er uretfærdigt, hvis naturlige eller sociale omstændigheder, som individet ikke kan kontrollere, påvirker fordelingen af vigtige goder (Roemer 1994, 147). Fordelingen burde i stedet afspejle individers indsats og valg to hensyn som ofte, men ikke nødvendigvis, er overlappende. Fundamentet herfor findes ofte i John Rawls' indflydelsesrige intuitive argument for differensprincippet - hans fordelingsprincip for ressourcer og goder i samfundet - som hævder, at et retfærdigt samfund bør kunne udligne forskelle, som skyldes det naturlige og det sociale lotteri (Rawls 1971, 74-75). Når ens stilling og muligheder i samfundet påvirkes negativt af sådanne omstændigheder, snakker man ofte om "bad brute luck". Ulighed på baggrund af dårlige omstændigheder, som det ikke med rimelighed står individet for at ændre, bør udlignes, fordi individet ikke kan holdes ansvarlig for at være dårligere stillet relativt til andre i samfundet. Kasper Lippert-Rasmussen opsummerer dette i én kernepåstand, som man ifølge ham skal kunne bekræfte, hvis man vil kalde sig en held-egalitarist:

"It is unjust if some people are worse off than others through their bad luck." (Lippert-Rasmussen 2015, 1)

Samtidig påpeger held-egalitarismen, at ulighed, der opstår som en konsekvens af folks frie, kalkulerede valg - hvad ofte benævnes "option luck" - ikke er problematisk ud fra et retfærdighedsmæssigt synspunkt, og at det dermed kun kan være af andre grunde, at sådan ulighed bør udlignes (Lippert-Rasmussen 2015, 3). At gøre personligt ansvar til en kilde til retfærdig ulighed udgør både en teoretisk korrektion til Rawls' differensprincip såvel som et modsvar til højrekritikken af den klassiske egalitarismes indifferens over for menneskers forskelligartede præferencer, dispositioner og villighed til arbejde hårdt (Albertsen 2013).

Den held-egalitaristiske retfærdighedsteori rækker i udgangspunktet langt ud over det spørgsmål om statsborgerskabskrav, som vi rejser i denne artikel, og der findes mange forskellige udformninger af held-egalitarisme. Nogle forsvarer held-egalitarismen udelukkende som en teori om social retfærdighed, som er nationalt afgrænset, men den mest udbredte version forsvarer held-egalitarismen som en global kosmopolitisk teori. Hvorvidt man i første omgang er indvandrer eller ej, er i sig selv et spørgsmål, som involverer en del tilfældighed. Af den grund er Rawls' intuitive argument og held-egalitarismen også ofte blevet anvendt til at problematisere den ekstremt ulige globale fordeling af ressourcer og muligheder. Inden for studier af global retfærdighed hævder kosmopolitter med den held-egalitaristiske intuition i ryggen, at velstående vestlige demokratier har omfattende omfordelingspligter overfor mindre velstående ikke-vestlige lande, da den nuværende fordeling ikke skyldes faktorer, som individerne selv har haft kontrol over (Tan 2012). 
Nogenlunde parallelt hermed hævder globalister indenfor statsborgerskabsstudier, ligeledes med henvisning til den held-egalitarismen, at det generelt er uretfærdigt, at ens statsborgerskab, som er afgørende for ens livsmuligheder, tildeles ved fødslen, når ingen kan påvirke, hvor de fødes (Shachar 2009). Held-egalitarismen rejser således helt fundamentale spørgsmål om retfærdighed i henhold til statsborgerskab, migration og den internationale orden.

Men disse spørgsmål ligger uden for den politiske kontekst, som danske politikere taler ind $\mathrm{i}$, når de udtaler sig om deres forventninger og krav til indvandrere. Her tages det for givet, at den danske stat og den danske befolkning er moralsk legitimeret $\mathrm{i}$ at sætte rammerne for, hvem der skal, og hvem der ikke skal, tilbydes statsborgerskab. Det betyder dermed ikke, at disse mere fundamentale spørgsmål er uinteressante eller uvidenskabelige, men blot at vores fokus her er på at evaluere styrken og gyldigheden af det argument om fairness, som politikerne leverer, i lyset af de faktisk gældende politiske omstændigheder. Vores udgangspunkt er derfor ikke de fundamentale normative spørgsmål eksemplificeret ovenfor, men om der kan gives en rimelig held-egalitaristisk begrundelse for at vurdere indvandreres ret til statsborgerskab på baggrund af indsats.

At danske politiske partier insisterer på, at statsborgerskab er noget, man gør sig fortjent til ved at gøre sit allerbedste for at integrere sig, virker til at kunne finde et forsvar i held-egalitarismen. Formen på sådan et argument vil være noget i denne stil:

P1 En ulige fordeling af vigtige sociale goder er (alt andet lige) retfærdig, hvis den afspejler folks indsats og fortjeneste, mens den er uretfærdig, hvis den skyldes faktorer, som folk ikke selv har kontrol over.

P2 Statsborgerskab er et vigtigt socialt gode.

P3 Hvorvidt man lever op til de danske krav for at blive tildelt statsborgerskab - sprogkrav, selvforsørgelseskrav, indfødsretsprøven mv. afspejler egen indsats og fortjeneste

K (fra P1-P3) Den ulige fordeling af statsborgerskab, som følger af de danske krav for tildeling af statsborgerskab, er (alt andet lige) retfærdig.

P1 er en normativ præmis, som udtrykker held-egalitarismen i sin grundform. At den er normativ, vil sige, at dens sandhedsværdi afhænger af plausibiliteten af en moralsk påstand, i dette tilfælde et held-egalitaristisk princip om retfærdighed. Præmissen påstår noget om, hvad der er moralsk sandt. Man kan således ikke måle eller teste P1 empirisk eller på anden vis give observerbar dokumentation for den. Snarere har præmissen karakter af at være et moralsk princip, som hviler på accepten af givne evaluative grunde (Nielsen 2013), herunder den hypotetiske intuitive grund, at hvis princippet er falsk, så fører det implikationer med sig, som vi ikke er villige til at acceptere. Man kan selvfølgelig være kritisk overfor, om P1 er sand, men det spørgsmål må således afklares i en analyse af de moralske grunde, som taler for og henholdsvis imod held-egalitarisme. At anfægte (eller forfægte) P1 kræver således saglig moralsk argumentation. 
Det er ikke vores ærinde her at diskutere P1, men det vil være gavnligt helt kortfattet at bemærke den oftest rejste grund til skepsis. Nogle kritikkere af held-egalitarismen mener, at vi bør afvise P1, fordi der kan gives eksempler på fordelingsmæssige udfald, som faktisk afspejler individers indsats, men som alligevel synes uretfærdige. Et kendt eksempel er motorcyklisten Bert, som fuldt informeret om risiko altid kører uden hjelm, fordi han elsker følelsen af vind i håret (Albertsen 2013; Fleurbaey 1995). Hvis Bert kommer alvorligt til skade og har brug for akut medicinsk behandling, så synes det for de fleste intuitivt uretfærdigt ikke at tilbyde Bert behandling, selvom hans tilstand skyldes egen indsats og fortjeneste. Held-egalitarister forsvarer sig blandt andet ved at henvise til andre moralprincipper, som retfærdighedsprincipper må suppleres med - hvorfor P1 også indeholder "alt andet lige" klausulen.

Andre kritikere mener, at der også findes eksempler på ulige fordelingsmæssige udfald, som ikke afspejler individers indsats, men som alligevel ikke synes uretfærdige, fx forskel i folks højde og dermed mulighed for bestemte jobs (Daniels 2008). Hvorvidt det taler imod P1, er uden for vores fokus her. Vi anerkender, at det er omstridt hvorvidt held-egalitarisme i sig selv er sand, men finder, at der er tilstrækkelig grunde til at acceptere, at P1 i de fleste tilfælde er et plausibelt udgangspunkt for en retfærdig fordeling.

P2 er sådan set også en normativ præmis. Den tager måske mere karakter af at være en definitorisk afgrænsning end et egentligt moralsk princip, men den har ligesom P1 også et normativt indhold. Den siger noget om, hvad statsborgerskab er, men også indirekte hvad det bør være. Hvorvidt P2 er sand afhænger af, hvad vi forstår, og bør forstå, ved statsborgerskab. Der er i litteraturen om statsborgerskab rimelig stor uenighed om, hvilken status statsborgerskabet egentlig bør have - både i juridisk, social, og moralsk forstand. Nogen statsborgerskabsforskere mener, at statsborgerskab bør gives automatisk til indvandrere med permanent opholdstilladelse, fordi det er udtryk for manglende respekt for individer, eller simpelthen fundamentalt udemokratisk, ikke at inkludere fastboende, som er er underlagt landets love, i det politiske liv (Dahl 1989, 129; Seglow 2009, 798; Carens 2013). Nogle mener sågar, at statsborgerskabet skal være ikke bare automatisk men også obligatorisk, fordi der med rettighederne følger vigtige borgerskabspligter (De Schutter og Ypi 2015). Men selvom der er uenighed om, hvilken indsats der kræves, så er der bred enighed om, at statsborgerskabet er et vigtigt socialt gode, som stiller visse krav til de indvandrere, som søger at opnå det (Jensen og Nielsen 2019).

I lyset af disse overordnede betragtninger, synes argumentet i høj grad af afhænge af P3. Denne præmis er i modsætning til de to foregående en empirisk påstand. Den hævder, at det er et spørgsmål om personlig indsats og fortjeneste, om man lever op til de danske krav for tildeling af statsborgerskab. Det er således et spørgsmål, som i princippet vil kunne finde en afklaring ved at kigge på data $i$ lyset af, hvad det rimeligvis vil sige, at noget er udtryk for egen vilje og indsats. Det spørgsmål søger vi at svare på i nedenstående afsnit. 
Om indsats og fortjeneste

At sige at indvandrere kun kan få adgang til det fulde sæt af rettigheder, som følger med statsborgerskab, ved at tage et vist ansvar for deres integration og gøre en tilstrækkelig indsats herfor, synes at stille dem over for et klart valg. De kan vælge at investere en høj grad af personlig indsats for at tilpasse sig det danske sprog, arbejdsmarked og samfund, eller de kan reducere deres indsatsniveau og alligevel håbe på, at det er nok til, at de kan få adgang til statsborgerskab på et tidspunkt. Indvandrere kan givetvis ikke på forhånd kalkulere præcist, hvad de kan opnå med en given indsats, men må operere med nogle forestillinger om, hvad der er sandsynligt. Disse sandsynlighedsbetragtninger kan selvfølgelig være forkerte, og det er en del af det sats, man laver, når man vælger sin indsats. Vil man være på den sikre side, investerer man sig fuldt ud i integrationsprocessen. Som minimum bør alle, der investerer sig fuldt ud i integrationsprocessen og yder en stor indsats, kunne efterleve kravene til statsborgerskab. Ellers er kravene ikke følsomme over for personlig indsats og frie valg.

Hvis danske politikere ønsker at forsvare statsborgerskabskrav, der er ufølsomme over for personlig indsats, skal de forsvare, at indvandrere ikke skal have lige muligheder for statsborgerskab. Altså at andre hensyn opvejer eller trumfer hensynet til fairness. Det er ikke et udtryk for fairness, hvis to indvandrere, som har ydet den samme indsats for at efterleve kravene, ikke har samme muligheder for at få statsborgerskab. De har begge udvist et sammenligneligt højt niveau af vilje til integration. John Roemer opsummerer det $\mathrm{i}$ denne generelle påstand:

"[E]quality of opportunity for X holds when the values of $X$ for all those who exercised a comparable degree of responsibility are equal, regardless of their circumstance." (Roemer 1994, 149).

Roemer fremhæver, at det ikke lader sig gøre at afdække den præcise grad af indsats individer investerer for at opnå et givent gode, men det er muligt at afdække, om to personer har ydet et tilstrækkeligt sammenligneligt indsatsniveau. Roemers forslag er at inddele populationen (indvandrere $\mathrm{i}$ denne diskussion) $\mathrm{i}$ grupper baseret på de for individet upåvirkelige baggrundsfaktorer, som samfundet ved påvirker individers evne til at omsætte ressourcer til adgang til et givent gode (statsborgerskab i denne diskussion). Al variation i opnåelsen af det givne gode, der opstår inden for grupper, som er ens i forhold til disse baggrundsfaktorer, kan så siges at afspejle variation i indsats. Variation mellem grupperne afspejler variationen i de bagvedliggende baggrundsfaktorer.

Hidtil har debatten og litteraturen om indvandringspolitik udelukkende fokuseret på en dikotomi imellem statsborgere og indvandrere, og dermed betragtet alle indvandrere (og alle statsborgere få den sags skyld) som værende medlemmer af samme gruppe i Roemers forstand. Men det involverer en klar og helt uberettiget undervurdering af forskellige baggrundsfaktorer. Som Lea Ypi påpeger, fører et system som det danske, hvor ind- 
vandrere skal leve op til bestemte og relativt høje krav, til, at indvandrere fra højere sociale klasser altid vil få privilegeret adgang til statsborgerskab på bekostning af indvandrere fra lavere klasser (Ypi 2018).

Set i dette lys synes det oplagt at problematisere den empiriske præmis (P3) i det held-egalitaristiske argument ovenfor. Det danske system stiller krav til egenskaber sprog, selvforsørgelse og viden - som oplagt varierer på tværs af forskellige relevante grupper af indvandrere, så indvandrere fra forskellige baggrunde har meget ulige muligheder for at leve op til kravene. Dertil kommer, at kravene er så stramme, at kun de allerfærreste (og dermed de allermest privilegerede indvandrere) kan opnå statsborgerskabsgodet. Dog er der fra et held-egalitaristisk synspunkt ikke i sig selv noget uretfærdigt i, at kravene er stramme, og at kun få kan få adgang. Problemet opstår, når kravene samtidig ikke er differentierede i forhold til ansøgernes arbitrære udgangspunkt for at kunne leve op til dem.

Derfor kan den danske proces ikke forsvares med det held-egalitaristiske argument. Hvis det er et ideal, at statsborgerskabskravene skal være fair, og at processen for tildeling af statsborgerskaber skal være åben og lige for alle, så er en differentiering af kravene baseret på indvandrernes forskellige udgangspunkter derfor påkrævet. De kommende afsnit problematiserer den empiriske præmis (P3) mere konkret i forhold til hver af de tre statsborgerskabskrav, idet det diskuteres, hvorvidt de enkelte krav hver især afspejler personligt ansvar, og det undersøges, hvordan kravene eventuelt kan udvikles til at differentiere på tværs af irrelevante baggrundsfaktorer.

\section{Sprogkrav}

Som beskrevet tidligere er de danske statsborgerskabskrav særdeles krævende sammenlignet med andre landes regler. Sprogkravet er ingen undtagelse. I dag skal alle indvandrere leve op til det samme høje sprogkrav på B2-niveau for at få adgang til dansk statsborgerskab. At bestå en prøve på B2-niveau kræver, at man kan tale, forstå og skrive dansk på et niveau, så man uhindret kan kommunikere med andre. Man forventes ikke at være så flydende i sproget, at man forstår implicit mening i tekster, at man ikke søger efter ord i samtale, eller at man kan producere tekst til professionel brug (Council of Europe 2001).

Danskundervisningen er indrettet således, at nyankomne flygtninge og familiesammenførte til flygtninge placeres på en af tre danskuddannelsesprogrammer - Dansk 1, 2 eller 3 - alt efter deres uddannelsesniveau. Dansk 1 afsluttes med en dansk-eksamen på A2-niveau, Dansk 2 afsluttes med eksamen på B1-niveau, mens Dansk 3 afsluttes med en eksamen på B2-niveau. Kun efter at have succesfuldt afsluttet ét danskuddannelsesforløb, kan man tilmeldes det næste. Hvert forløb er inddelt i seks moduler, som hver afsluttes med en prøve, som også skal bestås, før man kan rykke videre i programmet. Staten finansierer op til fem års danskundervisning fra første dag, man begynder på sit første danskuddannelsesprogram. Fem år efter denne dato ophører statens finansiering af 
danskundervisning. Det vil sige, at eventuelle mellemliggende pauser i personers danskundervisning ikke fraregnes.

Forskning i tilegnelse af et andetsprog viser ret entydigt en betydelig negativ effekt af alder (se fx Hakuta, Bialystok og Wiley 2003; Hou og Beiser 2006; van Tubergen 2010) og en betydelig positiv effekt af uddannelse (se fx Dustmann 1997; Hakuta, Bialystok og Wiley 2003; van Tubergen 2010). Alders-relaterede forandringer i kognition påvirker vores mulighed for at tilegne os et nyt sprog. Med alderen nedsættes evnen til at lære "paired associates", evnen til at afkode og bearbejde ny information og vi får mindre arbejdshukommelse (Craik and Jennings 1992; Kemper 1992; Salthouse 1992). Uddannelse træner til gengæld de kognitive evner, hjælper med tilegnelsen af gode læringsstrategier og skaber større selvtillid i forhold til at tilegne sig ny viden og sprog (Banks and Mazzona 2012; Ceci 1991). Således er yngre og bedre uddannede indvandrere i højere grad disponerede for at lære et nyt sprog. Analyser af sproguddannelserne i både Danmark og Norge bekræfter dette billede. Ældre indvandrere opnår i langt mindre grad en eksamen på B2-niveau, og kun en brøkdel af lavt uddannede indvandrere, som begynder på Dansk 1-programmet og det tilsvarende norske program, opnår over tid en eksamen på B2-niveau (Djuve et al. 2017; Jensen et al. 2019).

Hvis alder og uddannelse er baggrundsfaktorer, som indvandrere ikke kan kontrollere med deres personlige indsats, så bør sprogkravet differentieres i forhold til disse to faktorer, hvis vi accepterer præmissen om, at fordelingen af statsborgerskaber skal afspejle fairness. Alder er af åbenlyse grunde en baggrundsfaktor, som mennesker ikke kan kontrollere. Det er mindre åbenlyst med uddannelse. Hvilket uddannelsesniveau, indvandrere opnåede i deres oprindelsesland før deres ankomst til Danmark, har til dels været et resultat af deres egen indsats. At uddannelsesniveau alligevel skal behandles som en ukontrollerbar baggrundsfaktor skyldes to forhold: For det første, at indvandrere har haft forskellige muligheder for uddannelse i deres oprindelsesland. De vil derfor have opnået forskellige uddannelsesniveauer på trods af lignende indsatser - og nogle har været stærkt begrænsede i den indsats, de overhovedet har haft mulighed for at investere for at fremme deres uddannelse. Eksempelvis vil kvinder i en række lande have dårligere muligheder end mænd af andre grunde end personlig indsats. For det andet, ingen indvandrere har med rimelighed kunnet forudse, at det var nødvendigt at satse stort på uddannelse i hjemlandet, hvis de fremadrettet skulle have en god chance for dansk statsborgerskab. De har således ikke haft mulighed for at inddrage dette element som en del af et frit, kalkuleret valg. Desuden ville det kræve en ekstraordinær, hvis ikke umulig, indsats, hvis man først, som lavt uddannet indvandrer, skal opøve sine kognitive evner gennem mange års yderligere uddannelse på sit eget sprog for så at kunne deltage i et Dansk 3 forløb og i sidste ende bestå B2-prøven.

Hvad kan man så gøre for at gøre sprogkravet følsomt over for alder og uddannelse? En første mulighed er at differentiere sprogkravet, så de ældre og lavt uddannede skal bestå en sprogprøve på et lavere niveau end de yngre og højtuddannede. En oplagt mulighed er at kræve, at indvandrere består den afsluttende prøve på det danskforløb de placeres på. Det er allerede sådan, at kommunerne skal screene nyankomne flygtninge og 
familiesammenførte til flygtninge med henblik på at placere dem på det danskforløb, som svarer til deres uddannelsesniveau og forventede indlæringshastighed (hvor alder givet er en vigtig faktor). Dette kan udvides således, at alle indvandrere, som ønsker at begynde på et danskforløb, skal gennemgå en lignende screening. Ved således at kræve at de som begynder på Dansk 1 skal bestå en danskprøve på A2-niveau, hvorimod de som begynder på Dansk 3 skal bestå en prøve på B2-niveau, får man effektivt differentieret sprogkravet på baggrund af uddannelse og alder (hvis det specificeres, at dette skal indgå som et væsentligt kriterium i vurderingen af indlæringshastigheden).

Et alternativ eller supplement til at differentiere selve kravet er at differentiere på den offentlige sprogstøtte, som indvandrere modtager. Ældre og lavt uddannede skal således tilbydes flere års, flere timers og/eller mere støttende sprogundervisning end yngre og højtuddannede. Eksempelvis kan man oprette mindre klasser med to-lærer-ordninger til de indvandrere, som starter på Dansk 1 forløbet, samt gøre forløbet mere intenst med flere ugentlige timer. Det er dog nødvendigt, at den valgte tilgang ikke gør det sværere at imødekomme andre statsborgerskabskrav. Eksempelvis vil det, alt andet lige, være sværere at tage sig et arbejde, hvis man samtidig skal bruge en stor del af ugens timer på sprogundervisning.

\section{Videnskravet}

Foruden sprogkravet skal indvandrere, som ønsker dansk statsborgerskab, bestå indfødsretsprøven. Dette er en 'multiple choice' prøve, hvor man har 45 minutter til at besvare 40 spørgsmål om det danske samfund og dansk kultur. Svarene på 35 af spørgsmålene kan læses i det dertilhørende pensum (en bog på dansk om det danske samfund på ca. 200 sider) hvorimod de sidste fem spørgsmål er uden for pensum.

Indvandreres muligheder for at tilegne sig den nødvendige viden om samfundet samt forstå spørgsmålene i prøven forudsætter relativt gode danskkundskaber. De samme faktorer, som påvirker sprogtilegnelsen, vil således også indvirke på mulighederne for at bestå indfødsretsprøven. Indfødsretsprøven skal derfor også gøres følsom over for forskelle i alder og uddannelse, hvis den faktisk skal belønne personlig indsats. Ligesom ved sprogkravet kan det gøres ved at differentiere sværhedsgraden af prøven alt efter alder og uddannelse. De ældre og lavere uddannede vil så skulle bestå en prøve, hvor spørgsmålene er nemmere, er stillet i et mere simpelt sprog, hvor de får mere tid til at besvare, og/eller skal have færre svar rigtige for at bestå. En anden mulighed er, at prøverne og pensum udformes på flere sprog, samt at undervisningen i samfundsforhold foregår på flere sprog for de, som har sværere ved at tilegne sig dansk. Således vil man kunne fastholde et højere ambitionsniveau i forhold til den viden om det danske samfund, indvandrere skal tilegne sig, og hæve sværhedsgraden af prøven. 


\section{Selvforsørgelseskravet}

Statsborgerskab kræver også, at ansøgere ikke har modtaget hjælp efter lov om aktiv socialpolitik eller integrationsloven indenfor de sidste to år samt ikke mere end højst 4 måneder indenfor de sidste fem år. Ens muligheder for at få og beholde et arbejde, så man kan leve op til kravet, handler dog ikke blot om ens personlige indsats i forhold til at søge arbejde og efteruddanne sig. Igen viser forskning med tydelighed, at alder gør en betydelig forskel, men også de økonomiske konjunkturer samt diskrimination rammer nogle grupper hårdere end andre. Sprogtilegnelse, som vi ved påvirkes af alder og uddannelse, er afgørende for ens muligheder for at få fodfæste på arbejdsmarkedet (Dustmann og Fabri 2003; Himmler og Jäckle 2018). Indvandrere, som har sværere ved at lære sig det danske sprog, vil kunne søge et mindre udbud af jobs og være mindre eftertragtede blandt arbejdsgivere. Herudover er aldersdiskrimination på arbejdsmarkedet veldokumenteret (Truxillo et al. 2015; Wood, Wilkinson og Harcourt 2008). Særligt ældre mennesker har generelt sværere ved at få og fastholde et arbejde, hvilket man må formode også gør sig gældende blandt indvandrere.

Økonomiske konjunkturer er ligeledes afgørende for muligheden for arbejde. Under højkonjunkturer er efterspørgslen på arbejdskraft stor, mens den falder under lavkonjunkturer. Den enkelte indvandrer har selvfølgelig ingen kontrol over de makroøkonomiske forhold, hvilket bør afspejle sig i selvforsørgelseskravet, hvis det skal belønne personlig indsats. Således vil det kræve en større indsats at finde et arbejde under en lavkonjunktur, og selvforsørgelseskravet bør derfor lempes tilsvarende i sådanne perioder. Eksempelvis kan selvforsørgelseskravet differentieres alt efter arbejdsløshedsprocenten i de forudgående år, det relaterer sig til for den, som ansøger på et givent tidspunkt. Forskning viser dog, at lavt uddannede er i større risiko for at miste deres arbejde under lavkonjunkturer (Ammermueller, Kuckulenz og Zwick 2009). Ved at differentiere selvforsørgelseskravet i forhold til uddannelse vil man således kunne tage højde for en del af effekten fra lavkonjunkturer på mulighederne for at imødekomme selvforsørgelseskravet.

Endelig er der god evidens for etnisk diskrimination på arbejdsmarkedet, som særligt rammer bestemte etniske grupper. Indvandrere, som migrerer fra lande uden for Europa og Nordamerika, udsættes i højere grad for diskrimination i ansættelsesprocesser, men selv blandt disse eksisterer der også etniske hierarkier, hvor særligt indvandrere fra Mellemøsten og Afrika er i højere risiko for at blive diskrimineret (Midtbøen 2015; Zschirnt og Ruedin 2016). Så længe arbejdspladser i højere grad fravælger bestemte indvandrergrupper uden basis i indsats, bør indvandrere fra disse grupper stilles over for et mindre restriktivt selvforsørgelseskrav, hvis formålet med statsborgerskabsloven er, at indvandrere skal have lige muligheder for statsborgerskab og belønnes ligeligt for den samme indsats. 


\section{Konklusion}

Som vi har argumenteret for i denne artikel, kræver en fair procedure for tildelingen af statsborgerskab, at statsborgerskabskravene differentieres, så de bedre afspejler reel indsats fremfor ukontrollerbare baggrundsfaktorer. Selvom det umiddelbart lyder som en udvikling i retning af lempeligere udlændingepolitik, så er denne konklusion faktisk forenelig med en politik, som stiller meget høje krav til statsborgskab, så længe kravene afspejler indsats fremfor arbitrær privilegeret adgang. Artiklen har diskuteret nogle måder og områder, hvorpå en sådan differentiering kunne finde sted. En alternativ løsning, hvis statsborgerskabskravene i højere grad skal afspejle indsats, er også at give mulighed for dispensation fra kravene, hvis man kan påvise at have gjort sit bedste for at leve op til kravene, men at det simpelthen ikke kan lade sig gøre. Dette er også en mulighed i Danmark i dag selvom det er svært at få. Differentiering af kravene vil utvivlsomt gøre dispensation til et mindre nødvendigt værktøj, men gruppen af flygtninge hvis mentale helbred lider under traumatiske oplevelser vil stadig have behov for denne mulighed. I denne gruppe vil der være personer, hvis indlæringsevne er så begrænset, at meget lidt kan lade sig gøre i forhold til sprog, viden og selvforsørgelse.

Kritikere ville indvende, at de danske politikeres udtalelser ikke skal tolkes som indeholdende et ideal om held-egalitaristisk fairness, og at dette er helt rimeligt, da man i sammenhængskraftens navn nødvendigvis må stille høje krav til dem, som kommer til. Det vil sige, at på trods af indvandreres indsats og fortjeneste, så er der også bare noget, de skal kunne for at blive statsborgere - såsom at tale Dansk på B2 niveau. Men hvis man står fast på, at der er et absolut niveau af sprog eller selvforsørgelse, som man skal nå, så må man også sige, at indsats og fairness betyder mindre. Sætter man barren højt, så er der sandsynligvis kun en lille gruppe af de, som investerer sig fuldt ud, der faktisk kan leve op til kravene. Det vil kun være for denne lille gruppe, at politikken i så fald efterlever princippet om, at indsats skal belønnes. Resten udelukkes fra statsborgerskabet upåagtet deres arbejde for at integrere sig. Dette er givetvis en position, mange politikere vil forsvare, men i så fald kan de ikke gøre det med henvisning til fairness principper; at alle indvandrere skal gives nogenlunde lige muligheder i forhold til at få statsborgerskab.

\section{Litteratur}

Albertsen, A. (2013). Lader held-egalitarismen fanden tage de uansvarlige sidste? Politica, vol. 45(2), pp. 217-232.

Ammermueller, A., Kuckulenz, A. and Zwick, T. (2009). Aggregate unemployment decreases individual returns to education. Economics of Education Review, vol. 28(2), pp. 217-226.

Arneson, R.J. (2004). Luck Egalitarianism Interpreted and Defended. Philosophical Topics, vol. 32(1/2), pp. 1-20. 
Banks, J. and Mazzonna, F. (2012), The Effect of Education on Old Age Cognitive Abilities: Evidence from a Regression Discontinuity Design. The Economic Journal, vol. 122(560). https://doi.org/10.1111/j.1468-0297.2012.02499.x

Bech, E.C., Jensen, K.K., Mouritsen, P., and Olsen, T.V. (2017). Hvem er Folket? Flygtninge og Adgangen til Dansk Statsborgerskab. Politica, vol. 49(3), pp. 227-248.

Bevelander, P. and Pendakur, R. (2012). Citizenship, Co-Ethnic Populations, and Employment Probabilities of Immigrants in Sweden. Journal of International Migration and Integration, vol. 13(2), pp. 203-22. DOI: 10.1007/s12134-011-0212-6

Bevelander, P. (2015). Voting Participation of Immigrants in Sweden-a Cohort Analysis of the 2002, 2006 and 2010 Elections. Journal of International Migration and Integration, vol. 16(1), pp. 61-80. https://doi.org/10.1007/s12134-014-0332-x

Brezger, J., og Cassee, A. (2016). Debate: Immigrants and newcomers by birth—Do statist arguments imply a right to exclude both? Journal of Political Philosophy, vol. 24(3), pp. 367-378. https://doi.org/10.1111/jopp.12088

Carens, J. (2013). The Ethics of Immigration. Oxford: Oxford University Press.

Ceci, S.J. (1991). How much does schooling influence general intelligence and its cognitive components? A reassessment of the evidence. Developmental Psychology, vol. 27, pp. 703-722. https://doi.org/10.1037/0012-1649.27.5.703

Corluy, V., Marx, I. og Verbist, G. (2011). Employment Chances and Changes of Immigrants in Belgium: The Impact of Citizenship. International Journal of Comparative Sociology, vol. 52(4), pp. 350-68. https://doi.org/10.1177/0020715211 412112

Craik, F.I.M. and Jennings, J.M. (1992). Human memory. In: F.I.M. Craik \& T.A. Salthouse, eds., The Handbook of Aging and Cognition. Hillsdale, NJ: Erlbaum, pp. 51-110.

Council of Europe (2001). Common European Framework of Reference for Languages: Learning, Teaching, Assessment. Cambridge: Cambridge University Press.

Dahl, R. (1989). Democracy and its Critics. New Haven: Yale University Press.

Daniels, N. (2008). Just Health. Cambridge, MA: Cambridge University Press.

De Schutter, H. and Ypi, L. (2015). Mandatory citizenship for immigrants. British Journal of Political Science, vol. 45(2), pp. 235-251. https://doi.org/10.1017/S000712341 4000568

Djuve, A.B., Kavli, H.C., Sterri, E.B. and Bråten, B. (2017). Introduksjonsprogram og norskopplcering: Hva virker - for hvem?. Fafo-rapport 2017:31. Oslo: Fafo. Available at: https://www.fafo.no/images/pub/2017/20639.pdf

Dustmann, C. (1997). The Effects of Education, Parental Background and Ethnic Concentration on Language. The Quarterly Review of Economics and Finance, vol. 37, pp. 245-62. https://doi.org/10.1016/S1062-9769(97)90068-5.

Dustmann, C., Fabbri, F. (2003). Language Proficiency and Labour Market Performance of Immigrants in the UK. The Economic Journal, vol. 113(489), pp. 695-717. https://doi.org/10.1111/1468-0297.t01-1-00151 
Ferracioli, L. (2018). Citizenship for children: By soil, by blood, or by paternalism? Philosophical Studies, vol. 175, pp. 2859-2877. https://doi.org/10.1007/s11098-0170985-3

Fleurbaey, M. (1995). Equal Opportunity or Equal Social Outcome? Economics and Philosophy, vol. 11(1), pp. 25-55.

Gathmann, C. and Keller, N. (2018). Access to Citizenship and the Economic Assimilation of Immigrants. The Economic Journal, vol. 128(616), pp. 3141-81. https://doi.org/10.1111/ecoj.12546.

Hainmueller, J., Hangartner, D. and Pietrantuono, G. (2015). Naturalization Fosters the Long-Term Political Integration of Immigrants. Proceedings of the National Academy of Sciences, vol. 112(41), pp. 12651-56. https://doi.org/10.1073/pnas. 1418794112

Hainmueller, J., Hangartner, D. and Pietrantuono, G. (2017). Catalyst or Crown: Does Naturalization Promote the Long-Term Social Integration of Immigrants? American Political Science Review, vol. 111(2), pp. 256-76. https://doi.org/10.1017/ S0003055416000745

Hakuta, K., Bialystok, E. and Wiley, E. (2003). Critical Evidence: A Test of the CriticalPeriod Hypothesis for Second-Language Acquisition. Psychological Science, vol. 14(1), pp. 31-38. https://doi.org/10.1111/1467-9280.01415.

Hansen, K.J. (2018). Perceptions of Rich and Poor People's Efforts and Public Opinion about Economic Redistribution. PhD dissertation, Department of Political Science, Aarhus University. https://politica.dk/fileadmin/politica/Dokumenter/ph.d.afhandlinger/kristina_jessen.pdf

Himmler, O. and Jäckle, R. (2018), Literacy and the Migrant-Native Wage Gap. Review of Income and Wealth, vol. 64, pp. 592-625. https://doi.org/10.1111/roiw.12299

Hou, F. and Beiser, M. (2006). Learning the Language of a New Country: A Ten-Year Study of English Acquisition by South-East Asian Refugees in Canada. International Migration, vol. 44(1), pp. 135-65. https://doi.org/10.1111/j.14682435.2006.00358.x

Jensen, K.K. and Nielsen, L. (2019). Reconciling Automatic and Conditional Immigrant Naturalisation. Journal of Ethnic and Migration Studies, online published. https://doi.org/10.1080/1369183X.2019.1614437

Jensen, K.K., Mouritsen, P., Bech, E.C. and Olsen, T.V. (2019). Roadblocks to Citizenship: Selection Effects of Restrictive Naturalisation Rules. Journal of Ethnic and Migration Studies, online published. https://doi.org/10.1080/1369183X.2019. 1667757

Joppke, C. (2010). The Inevitable Lightening of Citizenship. European Journal of Sociology, vol. 51(1), pp. 9-32. https://doi.org/10.1017/S0003975610000019

Kemper, S. (1992). Language and aging. In: F.I.M. Craik \& T.A. Salthouse, eds., The Handbook of Aging and Cognition. Hillsdale, N.J: Erlbaum, pp. 213-270.

Lippert-Rasmusen, K. (2015). Luck Egalitarianism. London: Bloomsbury. 
Midtbøen, A.H. (2015). Ethnic Penalties In Western Labour Markets. Nordic Journal of Migration Research, vol. 5(4), pp. 185-193. https://doi.org/10.1515/njmr-20150022

Nielsen, L. (2013). Om metoden i normativ politologi. Politik, vol. 16(3), pp. 45-54.

Peters, F., Vink, M., and Schmeets, H. (2016) The ecology of immigrant naturalisation: a life course approach in the context of institutional conditions. Journal of Ethnic and Migration Studies, vol. 42(3), pp. 359-381. https://doi.org/10.1080/13691 83X.2015.1103173

Peters, F., Vink, M., and Schmeets, H. (2018). Anticipating the Citizenship Premium: Before and after Effects of Immigrant Naturalisation on Employment. Journal of Ethnic and Migration Studies, vol. 44(7), pp. 1051-80. https://doi.org/10.1080/ 1369183X.2017.1367650

Rawls, J. (1971). A Theory of Justice. Cambridge, MA: Harvard University Press.

Roemer, J. E. (1993). A Pragmatic Theory of Responsibility for the Egalitarian Planner. Philosophy \& Public Affairs, vol. 22(2), pp. 146-166.

Salthouse, T.A. (1992). Mechanisms of age-cognition relations in adulthood. Hillsdale, NJ: Erlbaum.

Seglow, J. (2009). Arguments for naturalisation. Political Studies, vol. 57(4), pp. 788804. https://doi.org/10.1111/j.1467-9248.2008.00768.x

Soysal, Y.N. (1994). Limits of Citizenship: Migrants and Postnational Membership in Europe. Chicago: The University of Chicago Press.

Street, A. (2017). The Political Effects of Immigrant Naturalization. International Migration Review, vol. 51(2), pp. 323-43. https://doi.org/10.1111/imre.12229

Truxillo, D.M., Finkelstein, L.M., Pytlovany, A.C. and Jenkins, J.S. (2015). Age Discrimination at Work: A Review of the Research and Recommendations for the Future. In: A.J. Colella and E.B. King, eds., The Oxford Handbook of Workplace Discrimination. Oxford: Oxford University Press.

Tubergen, F.v. (2010). Determinants of Second Language Proficiency among Refugees in the Netherlands. Social Forces, vol. 89(2), pp. 515-34. https://doi.org/10.1353/ sof.2010.0092

Wood, G., Wilkinson, A. and Harcourt, M. (2008), Age discrimination and working life: Perspectives and contestations - a review of the contemporary literature. International Journal of Management Reviews, vol. 10, pp. 425-442. https://doi.org/10. 1111/j.1468-2370.2008.00236.x

Zschirnt, E. and Ruedin, D. (2016). Ethnic discrimination in hiring decisions: a metaanalysis of correspondence tests 1990-2015. Journal of Ethnic and Migration Studies, vol. 42(7), pp. 1115-1134. https://doi.org/10.1080/1369183X.2015. 1133279

Ypi, L. (2018). Borders of Class: Migration and Citizenship in the Capitalist State. Ethics and international Affairs, vol. 32(2), pp. 141-152. https://doi.org/10.1017/S0892 679418000278 